\title{
In memoriam Prof. Dr. Leo P. ten Kate
}

\section{Martina C. Cornel ${ }^{1} \cdot$ Lidewij Henneman $^{1}$}

Published online: 16 November 2020

(C) Springer-Verlag GmbH Germany, part of Springer Nature 2020

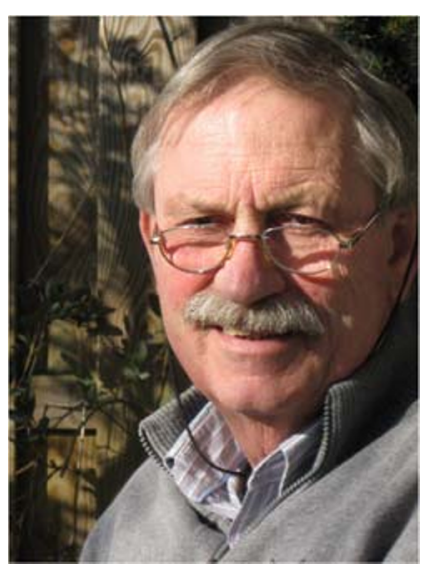

Leo Pieter ten Kate was born on 7 January 1940, at Medan, Sumatra, Indonesia. His father was a teacher in this former colony of The Netherlands. After the Second World War, the family moved back to The Netherlands. Once he finished medical school, Leo was trained in medical and clinical genetics by Professor George J.P.A. Anders at the Human Genetics Department of Groningen University, and as a postdoctoral fellow at the Division of Medical Genetics by Professor Arno G. Motulsky in Seattle, USA.

In 1975 he published his $\mathrm{PhD}$ thesis: "The frequency of cystic fibrosis: a genetic epidemiological study". Leo was very interested in population genetics. He investigated the birth prevalence of cystic fibrosis in the Netherlands, and arrived at an estimate of 1 in 3600 infants (Ten Kate 1977). This estimate was often cited in the decades thereafter, as well as

Martina C. Cornel

mc.cornel@amsterdamumc.nl

1 Department of Clinical Genetics, Amsterdam Public Health Research Institute and Amsterdam Reproduction \& Development Research Institute, Amsterdam UMC, Vrije Universiteit Amsterdam, Amsterdam, The Netherlands the derived carrier frequency $-2 q=1: 30$. Around that time, Leo tried to find a method for identifying cystic fibrosis in meconium samples as a neonatal screening method (Ten Kate et al. 1978). An earlier diagnosis would probably limit the health damage in these infants. It was only in 2011 that the Netherlands started cystic fibrosis screening in the national heelprick program, more than 30 years later. Obviously Leo was ahead of his time.

After this first successful population genetics study in Groningen, it was clear that the European Registration of Congenital Anomalies and Twins (EUROCAT) project would also start its Netherlands pilot in Groningen, with Leo ten Kate as first project leader (Boyd et al. 2011). For more than 3 decades, children born in the northern provinces of the Netherlands have been registered. EUROCAT surveillance relates to three areas: prevalence, primary prevention, and prenatal screening. Thus, many of his interests came together in this project.

In the middle of the 1980s, Leo's work still included cystic fibrosis, and in 1985 it became clear, by important efforts of others, that the CFTR gene was located on chromosome number 7. DNA restriction fragment length polymorphisms (RFLPs) were studied, to better define the precise location and to develop possibilities for prenatal diagnosis for families at risk. A major breakthrough for families and for the field of DNA diagnostics, several years before the identification of the gene in 1989.

From 1989 until 1993, Leo was professor by special appointment in Groningen, supported by the Dutch Genetic Alliance VSOP, the Netherlands umbrella organization for parents and patients involved in rare and genetic disorders. It was clear to Leo that what is at stake in science is not only the discovery of genes and their function, but in particular how you translate your findings to people. He counseled many families with genetic disorders in the clinic and started to think about genetic screening, in order to help these families and children by early identification of disease and to be able to start treatment before the first symptoms occur and thus avoid health 
damage. He had a special interest in ethical issues, and recognized that different people make different decisions in similar situations, based on their own values. He also remained interested in population genetics, and organized annual courses on "calculations in genetics". To illustrate risk estimation, he collected dices in different shapes and colors.

Subsequently he became Professor of Clinical Genetics and Head of the Department of Clinical Genetics in Amsterdam, VU University Medical Center, from 1993 till his retirement in 2005. His broad interests caused him to establish sections of Functional Genomics, Medical Genomics, Clinical Genetics, Community Genetics, Cytogenetics and Molecular Genetics at the Department. He supervised the graduation of many $\mathrm{PhD}$ students, including the two authors. He was always careful, upright, and systematic, and at the same time had strategic views about the future of genetics in health care.

He helped to organize the professional domain of clinical genetics, both in the Netherlands and in Europe as a member of the Public and Professional Policy Committee of the European Society of Human Genetics. He started to organize (inter)national meetings to introduce the topic of community genetics and its activities, including genetic screening, genetic education, and preconception care (Henneman et al. 2001). He initiated the Netherlands Association for Community Genetics (NACG) as well as the international journal Community Genetics. After serving the journal Community Genetics for 10 years, Leo said farewell (Ten Kate 2008). This coincided with the decision of the publisher to change the name of the journal to "Public Health Genomics" (Knoppers and Brand 2009), and the start of an international multidisciplinary community genetics e-mail network (Ten Kate 2008; Ten Kate and Plourde 2011). While temporally invisible, like a submarine, the concept resurfaced in 2010 as the Journal of Community Genetics (Schmidtke and Ten Kate 2010). In its first journal issue, the definition of community genetics was published (Ten Kate et al. 2010):

"Community Genetics is the art and science of the responsible and realistic application of health and diseaserelated genetics and genomics knowledge and technologies in human populations and communities to the benefit of individuals therein. Community Genetics is multi-, inter- and transdisciplinary and aims to maximize benefits while minimizing the risk of harm, respecting the autonomy of individuals and ensuring equity".

The definition illustrates very well the combination of Leo's interest in large-scale applications of human genetics, as well as continuous attention to the autonomy of the individual patient or couple. The importance that he saw in people with genetic conditions and their families was apparent from his ethical stances. The goal is not to reduce the birth prevalence, but to assist people in the choices that they want to make. With that attitude - respect for the people at stake - he has trained a generation of geneticists, $\mathrm{PhD}$ students, and researchers. His wise lessons and ideas have been shared with the younger generation, who in turn share it with their students.

After he retired, his health started to decline gradually. He still visited many conferences and meetings, walking carefully. Until March 2020 he worked very dutifully for the newsletter for the International Community Genetics Network. On 31 July 2020 his fruitful life came to an end, leaving his wife Martie, four children, and many grandchildren. A poem by the Dutch psychiatrist Rutger Kopland was printed on his mourning announcement card:

Leaving is different

from sneaking out of the house

and softly closing the door

behind your existence and not

returning. You remain

somebody whom people are waiting for.

Leaving can be described as

a sort of staying. Nobody

waits because you are still there.

Nobody says farewell,

because you're not leaving.

Let us remember professor Leo P. ten Kate as someone who still is there in the spirit of the Journal of Community Genetics.

\section{References}

Boyd PA, Haeusler M, Barisic I, Loane M, Garne E, Dolk H (2011) Paper 1: the EUROCAT network - organization and processes. Birth Defects Res A Clin Mol Teratol 91(Suppl 1):S2-S15. https://doi. org/10.1002/bdra.20780

Henneman L, Langendam MW, ten Kate LP (2001) Community genetics and its evaluation: a European Science Foundation workshop. Community Genet 4:56-59. https://doi.org/10.1159/000051157

Knoppers BM, Brand AM (2009) From community genetics to public health genomics - what's in a name? Public Health Genomics 12: 1-3. https://doi.org/10.1159/000153425

Schmidtke J, Ten Kate LP (2010) The Journal of Community Genetics. J Community Genet 1:1-2. https://doi.org/10.1007/s12687-0100008-y.

Ten Kate LP (1977) Cystic fibrosis in the Netherlands. Int J Epidemiol 6: 23-34. https://doi.org/10.1093/ije/6.1.23

Ten Kate LP (2008) Discharge and farewell. Community Genet 11:312. https://oi.org/10.1159/000133302

Ten Kate LP, Plourde A (2011) A short history of the first 3 years of the community genetics network and its newsletter. J Community Genet 2:111-115. https://doi.org/10.1007/s12687-011-0049-x 
Ten Kate LP, Feenstra-de Gooyer I, Ploeg-de Groot G, Gouw WL, Anders GL (1978) Should we screen all newborns for cystic fibrosis? Int J Epidemiol 7:323-330. https://doi.org/10.1093/ije/7.4.323

Ten Kate LP, Al-Gazali L, Anand S, Bittles A, Cassiman JJ, Christianson A, Cornel MC, Hamamy H, Kääriäinen H, Kristoffersson U, Marais D, Penchaszadeh VB, Rahman P, Schmidtke J (2010) Community genetics. Its definition 2010. J Community Genet 1:19-22. https:// doi.org/10.1007/s12687-010-0007-z

Publisher's note Springer Nature remains neutral with regard to jurisdictional claims in published maps and institutional affiliations. 